\title{
False ictal-appearing EEG from a frontal sinus pseudomeningocele
}

Figure 1 Head CT demonstrating left frontal pseudomeningocele

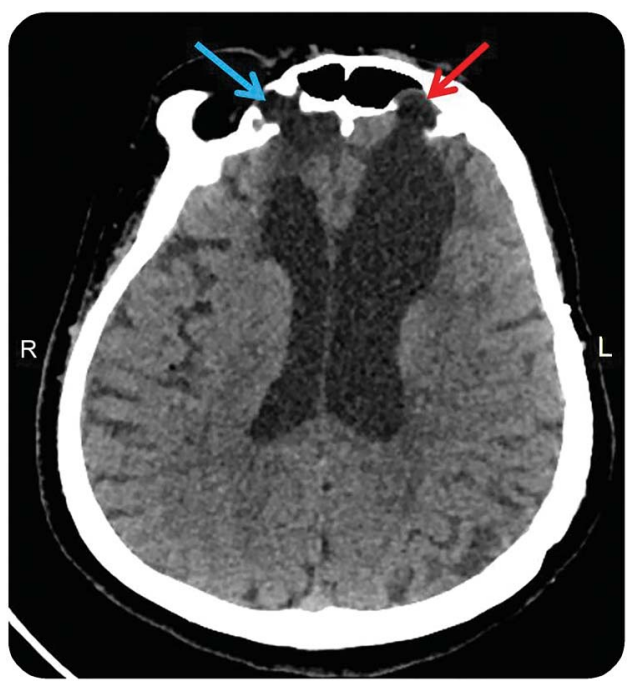

Left frontal pseudomeningocele (red arrow) and right frontal encephalocele (blue arrow)

A 71-year-old woman had 2 clusters of generalized convulsive seizures; a motor vehicle accident 21 years prior, resulting in a traumatic brain injury, was an epilepsy risk factor. Head CT showed extensive encephalomalacia and a pseudomeningocele extending within the left frontal sinus (figure 1). EEG showed rhythmic, heart rate time-locked pulsation artifact over the left frontopolar region with morphologic and amplitude

Figure 2 Longitudinal bipolar EEG demonstrating evolving pulsation artifact with superimposed ECG

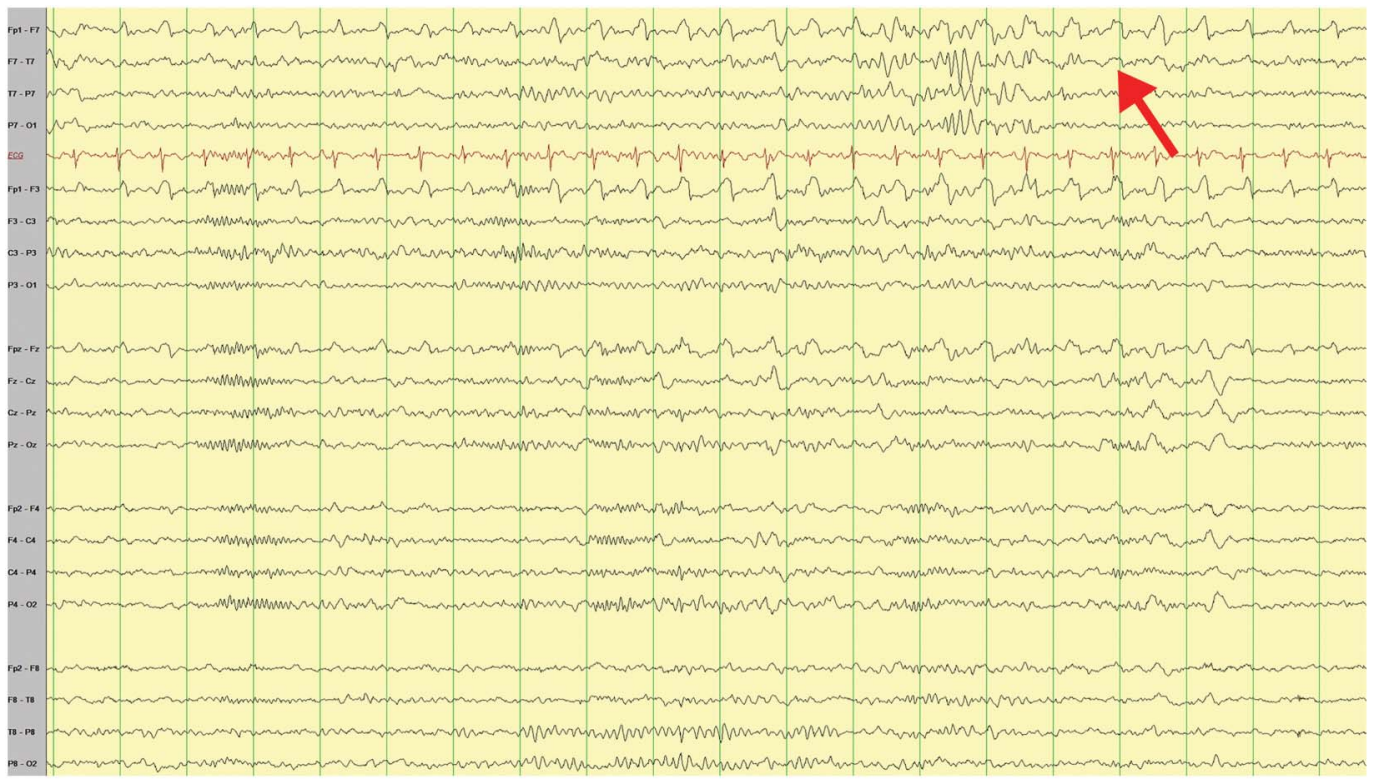

Left frontopolar rhythmic pulse artifact with pseudo-evolution, and "spread" briefly to F7 (arrow). 
pseudo-evolution (figure 2). Arterial pulsation was not palpable beneath the Fp1 electrode, and electrode repositioning did not alter its presence. ${ }^{1}$ Pseudomeningocele CSF pulsation is a source of artifact that can confound EEG interpretation by mimicking an ictal EEG discharge.

Adam Wallace, MD, Cheolsu Shin, MD, Elaine C. Wirrell, MD, David B. Burkholder, MD

From the Division of Epilepsy, Departments of Child and Adolescent Neurology (A.W., E.C.W.) and Neurology (C.S., D.B.B.), Mayo Clinic, Rochester, MN.

Author contributions: Adam Wallace: EEG interpretation, drafting the manuscript. Cheolsu Shin: patient treatment, study concept, and revising the manuscript for content. Elaine Wirrell: EEG interpretation and revising the manuscript for content. David Burkholder: patient treatment, drafting the manuscript, study supervision.

Study funding: No targeted funding reported.

Disclosure: The authors report no disclosures relevant to the manuscript. Go to Neurology.org for full disclosures.

Correspondence to Dr. Wallace: Wallace.Adam@mayo.edu

1. Dworetzky BA, Herman ST, Tatum WO. Artifacts of recording. In: Schomer DL, Lopes da Silva FH, editors. Niedermeyer's Electroencephalography, 6th ed. Philadelphia: Wolters Kluwer/Lippincott Williams \& Wilkins; 2011:239-266.

\section{Share Your Artistic Expressions in Neurology 'Visions'}

AAN members are urged to submit medically or scientifically related artistic images, such as photographs, photomicrographs, and paintings, to the "Visions" section of Neurology ${ }^{\circledR}$. These images are creative in nature, rather than the medically instructive images published in the NeuroImages section. The image or series of up to six images may be black and white or color and must fit into one published journal page. Accompanying description should be 100 words or less; the title should be a maximum of 96 characters including spaces and punctuation.

Learn more at www.aan.com/view/Visions, or upload a Visions submission at submit.neurology.org.

\section{Discover Altmetrics}

See real-time downloads and online activity for articles!

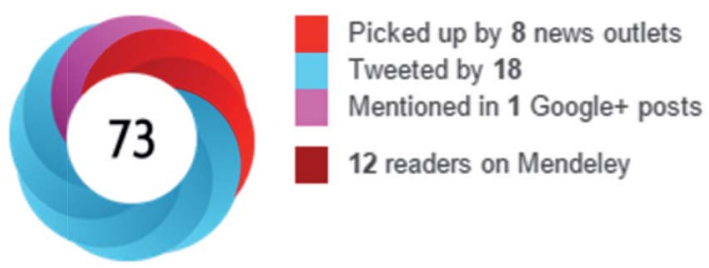

See more details

Authors and readers alike can view real-time data on articles including downloads and online activity across multiple sources. Click on the "Article Metrics" link in the right column of an article for details. To learn more about article metrics visit http://www.neurology.org/site/misc/article_usage.xhtml. 


\section{Neurology}

\section{False ictal-appearing EEG from a frontal sinus pseudomeningocele}

Adam Wallace, Cheolsu Shin, Elaine C. Wirrell, et al.

Neurology 2016;87;2600-2601

DOI 10.1212/WNL.0000000000003437

This information is current as of December 12, 2016

\section{Updated Information \&} Services

Subspecialty Collections

Permissions \& Licensing

\section{Reprints}

including high resolution figures, can be found at: http://n.neurology.org/content/87/24/2600.full

This article, along with others on similar topics, appears in the following collection(s):

\section{Brain trauma}

http://n.neurology.org/cgi/collection/brain_trauma

Cerebrospinal Fluid

http://n.neurology.org/cgi/collection/cerebrospinal_fluid

CT

http://n.neurology.org/cgi/collection/ct

EEG

http://n.neurology.org/cgi/collection/eeg

Information about reproducing this article in parts (figures,tables) or in its entirety can be found online at:

http://www.neurology.org/about/about_the_journal\#permissions

Information about ordering reprints can be found online:

http://n.neurology.org/subscribers/advertise

Neurology ${ }^{\circledR}$ is the official journal of the American Academy of Neurology. Published continuously since 1951, it is now a weekly with 48 issues per year. Copyright () 2016 American Academy of Neurology. All rights reserved. Print ISSN: 0028-3878. Online ISSN: 1526-632X.

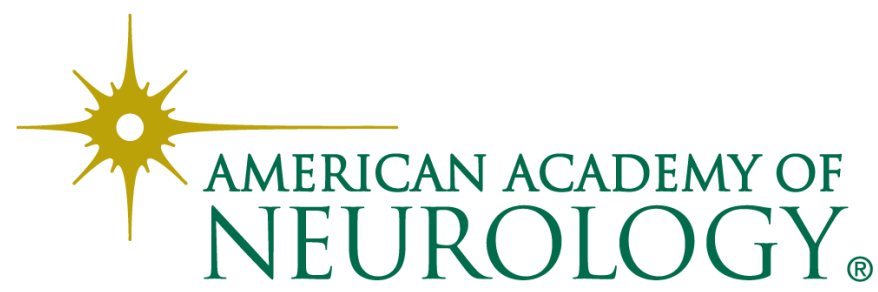

